DOI: https://doi.org/10.47405/mjssh.v6i4.771

\begin{tabular}{|c|c|}
\hline 4.581 & Malaysian Journal of Social Sciences and Humanities (MJSSH) \\
\hline $\begin{array}{l}\text { Malaysian Journal of } \\
\text { Social cciences and }\end{array}$ & Volume 6, Issue 4, April 2021 \\
\hline (MJ-SSH) & e-ISSN : 2504-8562 \\
\hline & $\begin{array}{l}\text { Journal home page: } \\
\text { www.msocialsciences.com }\end{array}$ \\
\hline
\end{tabular}

\title{
Hubungan antara Kepuasan Kerja dan Kesihatan Psikologi dalam kalangan Pekerja Wanita di Kementerian Belia dan Sukan, Putrajaya
}

\author{
Nur Syahirah Rosli ${ }^{1}$, Norlena Salamuddin ${ }^{1}$ \\ ${ }^{1}$ Fakulti Pendidikan, Universiti Kebangsaan Malaysia (UKM)
}

Correspondence: Nur Syahirah Rosli (p98017@siswa.ukm.edu.my)

\begin{abstract}
Abstrak
Kajian ini dijalankan bertujuan untuk mengkaji hubungan antara kepuasan kerja dan kesihatan psikologi dalam kalangan pekerja wanita di Kementerian Belia dan Sukan (KBS), Putrajaya. Borang soal selidik Job Satisfaction Survey (Spector, P. E. 1997) diguna pakai untuk mengukur lima faktor kepuasan kerja, iaitu gaji, penyeliaan, suasana pekerjaan, rakan sekerja dan kenaikan pangkat. Manakala General Health Question (Goldberg and Hillier, 1979) diguna pakai untuk mengukur tiga dimensi kesihatan psikologi, iaitu kegelisahan dan insomnia, disfungsi sosial dan kemurungan. Seramai 175 pekerja wanita di KBS terlibat dalam kajian ini. Dapatan kajian menunjukkan terdapat hubungan yang negatif antara kepuasan kerja dan kesihatan psikologi. Hasil penyelidikan ini dapat disimpulkan bahawa kepuasan kerja dan kesihatan psikologi adalah penyebab penting kepada kesihatan pekerja. Apabila pekerja berasa gembira dengan kerja mereka, mereka menjadi lebih produktif dan cenderung untuk menjadi lebih sihat. Apabila pekerja merasa tertekan dengan bebanan kerja, dan secara tidak langsung boleh mempengaruhi kesihatan mereka. Cadangan kajian adalah agar lebih banyak kajian yang dibuat dengan lebih luas dan terbuka dan pemboleh ubah lain yang mempunyai kesan terhadap kepuasan kerja dan kesihatan psikologi pekerja juga diambil kira. Sebagai contoh, hubungan antara kepuasan kerja dan kesihatan psikologi di kalangan pekerja wanita perlu dibandingkan pada kedua-dua sektor iaitu sektor kerajaan dan swasta untuk melihat perbezaan faktor kepuasan kerja dan juga faktor kesihatan psikologi dalam kalangan pekerja wanita di Malaysia yang mungkin dipengaruhi oleh faktor lain.
\end{abstract}

Kata kunci: kepuasan kerja, kesihatan psikologi, pekerja wanita

\section{Relationship Between Job Satisfaction and Psychological Health Among Female Employees at Ministry of Youth and Sports, Putrajaya}

\begin{abstract}
This study aimed to examine the relationship between job satisfaction and psychological health among female employees at Ministry of Youth and Sports, Putrajaya. The data were collected by using questionnaires. The study sample consisted of female employees of Ministry of Youth and Sports, Putrajaya which has a total of 175 respondents participated in this study. Job Satisfaction Survey (JSS; Spector, 1985) were used to measure five factors of job satisfaction, include pay, supervision, nature of work, coworkers and promotion. While General Health Questionnaire (GHQ; Goldberg 1978) were used to measured three dimension of psychological health that include anxiety \& insomnia, social dysfunction and depression. The research shows that there is an existing negative relationship between
\end{abstract}


job satisfaction and psychological health. Through this study, it can be concluded that job satisfaction and psychological health are vital aspects of an employees' health. When employees feel contended at work, they tend to become more productive and healthier. Thus, it can be said that when employees feel stressed caused by workloads, it can indirectly influence their health. In order to identify impacts on job satisfaction and psychological health of employees, it is recommended for further studies to be done more extensively and openly so that other variables can be taken into account to this matter. For example, the relationship between job satisfaction and psychological health among female employees should be compared between both the government and private sectors to see the differences in job satisfaction factors as well as psychological health factors among female employees in Malaysia that may be affected by other factors.

Keywords: job satisfaction, psychological health, female employees

\section{Pengenalan}

Kepuasan kerja adalah indikator kepada penzahiran rasa seronok, selesa, dan tenteram atau perasaan positif yang terhasil daripada pengalaman kerja atau suatu sikap yang terhasil daripada kepuasan emosi individu terhadap pekerjaannya (Fatimah Affendi, 2014). Selain itu, kepuasan kerja boleh didefinisikan sebagai rasa pencapaian pekerja dan kejayaan mereka dalam pekerjaan. Ia secara amnya dianggap berkaitan dengan produktiviti dan juga kesejahteraan pesuasana kerja. Menurut Kaliski (2007), kepuasan kerja juga membawa maksud pekerja yang melaksanakan sesuatu pekerjaan mereka dengan perasaan yang gembira. Kepuasan kerja menunjukkan semangat pekerja itu dalam melakukan sesuatu tugasan yang diberi tanpa berasa tertekan. Oleh itu, kepuasan kerja merupakan kunci utama yang membawa kepada faktor kepuasan kerja itu sebagai contoh, faktor gaji, penyeliaan, suasana kerja rakan sekerja dan kenaikan pangkat.

Kepuasan kerja ini melibatkan perasaan positif atau negatif seseorang terhadap pekerjaannya. Kepuasan kerja merujuk kepada tahap kepuasan pekerja di dalam organisasi terhadap pekerjaan dan persekitaran kerja mereka (Fatimah Affendi, 2014). Menurut Sinha (1974), Baro dan Mahavidyalaya (2014), kepuasan kerja boleh difahami dengan maksud "keadaan emosi yang menyenangkan hasil daripada penilaian seseorang terhadap kehendaknya yang selaras dengan apa yang ada dalam pekerjaannya". Kepuasan kerja juga menerangkan bagaimana seorang pekerja suka dengan pekerjaan mereka (Locke 1969; Chin et al., 2017). Sesetengah pandangan menyatakan kepuasan kerja adalah penting kerana ianya merupakan salah satu aspek utama dalam membentuk pekerja yang bermotivasi dan berprestasi tinggi (Mullins, 2002).

Manakala bagi kesihatan psikologi pula, ianya ditakrifkan sebagai perkaitan yang melibatkan emosi, tingkah laku, dan sosial yang normal kepada seseorang (Banks, 1980; Nahar et al., 2013). Kesihatan psikologi juga boleh didefinisikan sebagai satu kajian tentang penyakit yang dilihat dari pelbagai perspektif biologikal, psikologikal dan sosiologikal dan juga menumpukan aspek-aspek klinikal, penjagaan kesihatan dan perubatan dalam usaha untuk meningkatkan kesihatan fizikal dan kesejahteraan individu atau pekerja. Menurut Baro dan Mahavidyalaya, (2014), pada masa ini kesihatan mental telah dikenali sebagai faktor yang penting dalam status kesejahteraan seseorang untuk menekankan betapa pentingnya kesejahteraan fizikal dan juga pencapaian sosial di tempat kerja.

Dari perspektif kajian ilmiah di Malaysia, kepuasan kerja dan kesihatan psikologi telah banyak dibincangkan. Sebagai contoh kajian dari Haryati (2013) yang menyatakan kesihatan boleh menjejaskan produktiviti serta kualiti pekerja jika tidak ditangani dengan baik dan berkesan. Justeru, kesihatan psikologi boleh memberi kesan yang negatif terhadap kesihatan pekerja dan kesejahteraan hidup individu itu sendiri. Oleh itu pengkaji ingin menyelidiki adakah terdapat sebarang hubungan antara kepuasan kerja dan kesihatan psikologi terhadap responden dalam kajian ini. 


\section{Sorotan Literatur}

\section{Definisi Kepuasan kerja dan Kesihatan Psikologi}

Menurut Halimatussaediya dan Noraini (2015), kepuasan kerja boleh didefinisikan sebagai satu keseronokan atau perasaan positif hasil daripada nilaian sesuatu kerja atau pengalaman kerja. Perasaan ini timbul daripada persepsi setiap pekerja yang menggambarkan nilai-nilai sebenar kerja mereka dalam situasi kerja (Ramli, 2000). Kepuasan kerja juga melibatkan interaksi antara pekerja dengan pekerjaannya (Ahmad Jawaher, 2000). Kepuasan kerja dapat difahami sebagai hasil yang wujud berdasarkan pandangan pekerja terhadap pekerjaan mereka khususnya bagaimana keadaan kerja mereka menyediakan perkara-perkara yang dilihat sebagai penting (Bowling et al., 2006; Kuruüzüm et al., 2009).

Kajian yang dilakukan oleh Aazami et al. (2015) mendapati bahawa hubungan antara kepuasan kerja dan kesihatan psikologi turut mempengaruhi kepuasan kerja individu. Mereka menemukan bahawa emosi yang ditunjukkan dalam persekitaran kerja adalah dipengaruhi oleh sasaran yang ditentukan oleh individu seperti marah dengan seseorang atau bangga dengan pencapaian yang dicapai. Kedua-dua emosi ini akan mempengaruhi tahap kepuasan kerja individu. Aazami et al. (2015) menyatakan hubungan interpersonal dalam organisasi akan menjadi lebih tegang jika situasi ini ditambah dengan tindak balas emosi terhadap situasi lain seperti isu upah dan peluang kenaikan pangkat yang tidak adil.

Kesihatan psikologi yang melibatkan kegelisahan, kemurungan, gangguan tidur dan gejala-gejala lain turut menjadi masalah dominan di kalangan komuniti tempat kerja (Action, 2015). Menurutnya, keadaan ini terjadi apabila keadaan mental individu yang merasa satu tahap kepuasan terhadap perubahan sosial dan mental dalam diri mereka. Kesihatan psikologi menurut Persatuan Psikiatri Amerika (2000) yang ditulis dalam jurnal (Nadinloyi et al., 2013) membawa maksud individu yang pada asalnya mempunyai masalah dalaman seperti cara berinteraksi dengan individu lain dan diri sendiri. Keadaan ini terjadi disebabkan percanggahan pendapat yang tidak dapat dielakkan dan dilempar secara terbuka. Kesihatan psikologi juga merujuk kepada keupayaan individu untuk bekerja.

Pekerja boleh mengamalkan senaman yang bermanfaat bagi menghilangkan tekanan semasa bekerja serta menyesuaikan diri dengan sebarang perubahan dan masalah (Mohamad et al., 2017). Menurut Yahaya dan Yin (2007), penyakit psikologi boleh dibahagikan kepada dua kelas utama iaitu maniak dan waras. Kesihatan psikologi telah dikaitkan dengan keadaan pekerjaan sebagai contoh kerja yang melibatkan keupayaan mental yang tinggi dan fleksibiliti yang rendah. Hal ini perlu dibendung dari awal untuk mengelakkan pekerja dari mengalami masalah ini di tempat kerja seterusnya memberikan kesan terdapat kepuasan kerja dan kesihatan psikologi mereka yang bekerja.

\section{Teori}

Menurut Herzberg's Hygiene-Motivation Theory, kepuasan kerja dan ketidakpuasan kerja adalah dua perkara yang berbeza. Kepuasan dan ketidakpuasan terhadap kerja bukanlah suatu pemboleh ubah yang berterusan. Teori ini merumuskan tentang ciri-ciri kerja yang diselidiki pengkaji sehingga terbahagi kepada dua kumpulan sama ada memuaskan atau tidak memuaskan. Kepuasan adalah faktor atau situasi yang diperlukan sebagai sumber kepuasan kerja yang terdiri daripada kerja yang menarik, penuh dengan cabaran, berpeluang untuk meningkatkan prestasi, peluang untuk mendapat pengiktirafan dan kenaikan pangkat. Pemenuhan faktor-faktor ini akan membawa kepada kepuasan, tetapi ianya tidak selalu membawa kepada ketidakpuasan. Faktor yang menjadi sumber ketidakpuasan antaranya terdiri daripada gaji/upah, penyeliaan, hubungan interpersonal, keadaan dan status kerja. Faktor-faktor ini diperlukan untuk memenuhi dorongan biologi dan keperluan asas pekerja. Sekiranya faktor-faktor ini tidak dapat dipenuhi, pekerja tidak akan berpuas hati. Walau bagaimanapun, sekiranya faktor ini mencukupi untuk memenuhi keperluan, pekerja tidak akan kecewa walaupun mereka tidak berpuas hati.

Kajian ini bertujuan untuk melihat kepuasan kerja dari perspektif Herzberg's Hygiene-Motivation Theory yang telah diselidiki oleh ramai pengkaji terdahulu untuk mengkaji kepuasan kerja (Temple, 
2013; Steingrímsdóttir, 2012). Teori ini menentukan bahawa aspek yang berbeza mampu menyumbang kepada ketidakpuasan dan kepuasan kerja. Ianya juga memberi penekanan untuk mengenali keperluan dan kekuatan seseorang individu. Teori Herzberg mengkategorikan faktor-faktor yang mempengaruhi kepuasan kerja hygiene-motivation. Faktor hygiene seperti dasar organisasi, gaji, penyeliaan, hubungan rakan sekerja, keselamatan kerja dan keadaan kerja boleh menyebabkan ketidakpuasan kerja dan tidak dapat meningkatkan prestasi kerja. Manakala faktor motivasi seperti pengiktirafan, pencapaian, kenaikan pangkat, kerja, dan tanggungjawab boleh menyebabkan kepuasan kerja, namun tidak mengurangkan tahap rasa tidak puas hati (Herzberg et al., 1959).

Pengkaji berpendapat bahawa adalah sangat penting untuk memenuhi elemen hygiene untuk mengurangkan ketidakpuasan kerja. Tumpuan juga perlu diberikan pada elemen motivation untuk meningkatkan tahap kepuasan kerja. Aspek hygiene juga harus diberikan perhatian penting bagi mengelakkan perasaan buruk dan negatif di tempat kerja. Selain daripada itu, aspek motivation merupakan faktor lain yang mendorong pekerja di tempat kerja (Herzberg, 1966). Secara ringkasnya, faktor hygiene antaranya menjadi penentu terhadap aspek pekerjaan sama ada pekerja menjadi berpuas hati atau tidak berpuas hati terhadap sesuatu pekerjaan. Sebaliknya, faktor motivation menyatakan berkenaan aspek kerja yang memberikan kepuasan kerja kepada pekerja).

\section{Metod Kajian}

Kajian ini menggunakan pendekatan kuantitatif yang menggunakan reka bentuk tinjauan dan seramai 175 orang pekerja wanita dari Kementerian Belia dan Sukan (Putrajaya) telah dipilih sebagai sampel kajian berdasarkan penentuan saiz sampel Krejcie dan Morgan yang telah menyenaraikan saiz sampel yang berpadanan dengan saiz populasi kajian. Sampel dipilih melalui kaedah persampelan bertujuan, iaitu prosedur persampelan daripada sekumpulan responden yang mempunyai ciri-ciri dan tujuan khusus yang telah ditetapkan oleh pengkaji seperti jantina. Responden merupakan 175 orang pekerja wanita yang bekerja di Kementerian Belia dan Sukan (Putrajaya). Responden berumur antara 21 tahun hingga 60 tahun. Responden diminta melengkapkan dan menjawab kesemua soalan dalam borang soal selidik. Instrumen kajian pula mengadaptasi soal selidik daripada Job Satisfaction Survey yang diadaptasi daripada Spector (1997) untuk mengkaji faktor kepuasan kerja yang mengandungi aspek 5 faktor iaitu gaji (pay), penyeliaan (supervisor), suasana kerja (nature of work), rakan sekerja (coworkers) dan kenaikan pangkat (promotion). Seterusnya, pengkaji telah menggunakan instrumen soal selidik General Health Question yang diadaptasi daripada (Goldberg \& Hillier, 1979) untuk mengkaji faktor kesihatan psikologi yang mengandungi aspek 3 faktor yang hanya melihat sebahagian daripada faktor kesihatan psikologi iaitu kegelisahan dan insomnia (anxiety and insomnia), disfungsi sosial (social dysfunction) dan kemurungan (depression). Analisis deskriptif melibatkan nilai kekerapan, peratus, min dan sisihan piawai manakala analisis inferensi menggunakan Ujian Korelasi Pearson. Hasil ujian rintis mencatatkan nilai kebolehpercayaan alpha Cronbach, $\alpha$ bagi Instrumen Kepuasan Kerja adalah 0.96 dan Kesihatan Psikologi ialah 0.85.

\section{Hasil Kajian}

\section{Analisis Deskriptif}

Analisis deskriptif digunakan untuk memberi gambaran umum bagi data kajian yang diperoleh daripada responden. Analisis deskriptif menghuraikan berkenaan dapatan demografi pekerja wanita dan juga melihat taburan min dan sisihan faktor kepuasan kerja dan kesihatan psikologi. Jadual 1 menunjukkan interpretasi skor min bagi faktor kepuasan kerja dan kesihatan psikologi.

Jadual 1: Interpretasi skor min

\begin{tabular}{cc}
\hline Skor $\min$ & Interprestasi skor min \\
\hline $1.00-2.33$ & Rendah \\
$2.34-3.66$ & Sederhana
\end{tabular}


Jamil Ahmad (2002)

\section{Profil Demografi Pekerja Wanita di KBS}

Maklumat demografi pekerja wanita yang dibincangkan adalah umur, tahap pengajian dan pendapatan bulanan. Kajian ini melibatkan seramai 175 orang pekerja wanita di KBS. Jadual 2 menunjukkan dapatan kajian demografi pekerja wanita secara terperinci

Jadual 2: Profil demografi pekerja wanita

\begin{tabular}{ccc}
\hline Ciri-ciri responden & Kekerapan (n) & Peratusan (\%) \\
Umur & 109 & 62.3 \\
$21-30$ & 40 & 22.9 \\
$31-40$ & 23 & 13.1 \\
$41-50$ & 3 & 1.7 \\
$51-60$ & & \\
Pendapatan Bulanan & & \\
RM 1000-RM 2999 & 85 & 48.6 \\
RM 3000- RM 4999 & 84 & 48.0 \\
RM 5000-RM 6999 & 6 & 3.4 \\
& & \\
Tahap Pendidikan & 70 & 40.0 \\
SPM & 38 & 21.7 \\
STPM & 17 & 9.7 \\
DIPLOMA & 46 & 26.3 \\
IJAZAH & 2 & 1.1 \\
SARJANA & 2 & 1.1 \\
PHD & &
\end{tabular}

Berdasarkan jadual 2 di atas, daripada 175 orang responden taburan mengikut umur pula menunjukkan seramai 109 orang responden (62.3\%) berusia dalam lingkungan umur 21 hingga 30 tahun, 40 orang responden (22.9\%) berusia dalam lingkungan umur 31 hingga 40 tahun. Responden dalam lingkungan umur 41 hingga 50 tahun pula adalah seramai 23 orang (13.1\%) dan hanya 3 orang sahaja responden $(1.7 \%)$ yang berusia dalam lingkungan umur 51 hingga 60 tahun.

Seterusnya, seramai 85 responden iaitu $48.6 \%$ memperoleh gaji dalam lingkungan RM1000 hingga RM2999 diikuti dengan 84 responden iaitu 48.0\%, memperoleh gaji dalam lingkungan RM3000 hingga RM4999. Seramai 6 responden (3.4\%), memperoleh gaji dalam lingkungan RM5000 hingga RM6999.

Akhir sekali, majoriti responden mempunyai latar belakang pendidikan sehingga tahap SPM iaitu seramai 70 orang (40.0\%) diikuti dengan tahap STPM iaitu seramai 38 orang (21.7\%). Seramai 17 orang responden $(9.7 \%)$ yang mempunyai latar belakang pendidikan pada peringkat diploma, 46 orang responden $(26.3 \%)$ pada peringkat ijazah dan hanya 2 sahaja responden $(1.1 \%)$ yang mempunyai latar belakang pendidikan pada tahap sarjana. Manakala 2 responden lagi (1.1\%) mempunyai tahap pendidikan selain daripada yang telah dinyatakan tadi iaitu pada tahap PHD.

\section{Faktor Kepuasan Kerja}

Jadual 3 menunjukkan analisis deskriptif bagi faktor kepuasan kerja. Nilai min adalah nilai purata bagi keseluruhan jawapan daripada responden. Pengkaji menjalankan analisis min dan sisihan piawai untuk mengenal pasti tahap kepuasan kerja. Hal ini demikian kerana min dan sisihan piawai adalah asas kepada keseluruhan analisis serta penghuraian dapatan kajian. 
DOI: https://doi.org/10.47405/mjssh.v6i4.771

Jadual 3: Analisis deskriptif faktor kepuasan kerja

\begin{tabular}{cccc}
\hline & Min & Sisihan Piawai & Tahap \\
\hline Gaji & 3.61 & 0.36 & Sederhana \\
Penyeliaan & 4.02 & 0.58 & Tinggi \\
Suasana kerja & 3.89 & 0.45 & Tinggi \\
Rakan sekerja & 3.52 & 0.52 & Sederhana \\
Kenaikan Pangkat & 3.63 & 0.63 & Sederhana \\
\hline Keseluruhan (Kepuasan Kerja) & 3.73 & 0.26 & Tinggi \\
\hline (Tahap: Rendah $=1.00-2.33$, Sedera
\end{tabular}

(Tahap: Rendah $=1.00-2.33$, Sederhana $=2.34-3.66$, Tinggi $=3.67-5.00)$

Dalam kajian ini, kepuasan kerja diukur oleh empat faktor, iaitu gaji, penyeliaan, rakan sekerja, suasana kerja dan kenaikan pangkat. Hasil kajian daripada jadual 4.3 menunjukkan bahawa faktor penyeliaan mempunyai nilai $\min (\min =4.02, \mathrm{SP}=0.58)$ berada pada tahap yang tinggi. Seterusnya diikuti oleh faktor suasana kerja $(\min =3.89, \mathrm{SP}=0.45)$ juga berada pada tahap yang tinggi manakala faktor kenaikan pangkat $(\min =3.63, \mathrm{SP}=0.63)$ berada pada tahap sederhana. Seterusnya, faktor gaji $(\mathrm{min}=$ $3.61, \mathrm{SP}=0.36$ ) juga berada pada tahap sederhana dan faktor rakan sekerja mempunyai min yang paling rendah $(\min =3.52, \mathrm{SP}=0.52)$ juga berada pada tahap yang sederhana. Secara keseluruhan menunjukkan bahawa skor kepuasan kerja $(\min =3.37, \mathrm{SP}=0.26)$ dalam kalangan pekerja wanita di KBS berada pada tahap yang tinggi.

\section{Faktor Kesihatan Psikologi}

Jadual 4 menunjukkan tahap skor min faktor kesihatan psikologi, iaitu kegelisahan dan insomnia, disfungsi sosial dan kemurungan. Daripada dapatan yang diperolehi menunjukkan nilai skor min bagi faktor kegelisahan dan insomnia adalah $(\min =1.32, \mathrm{SP}=0.32)$. Manakala item yang mempunyai tahap yang rendah adalah faktor disfungsi sosial $(\min =1.27, \mathrm{SP}=0.29)$, Seterusnya, faktor kemurungan mempunyai min yang paling rendah $(\min =1.08, \mathrm{SP}=0.22)$ berada pada tahap yang rendah. Secara keseluruhan menunjukkan bahawa skor kesihatan psikologi $(\mathrm{min}=1.27, \mathrm{SP}=$ $0.25)$ dalam kalangan pekerja wanita di KBS.

Jadual 4: Analisis deskriptif faktor kesihatan psikologi

\begin{tabular}{cccl}
\hline & Min & Sisihan Piawai & Tahap \\
\hline Kegelisahan \& Insomnia & 1.32 & 0.32 & Rendah \\
Disfungsi Sosial & 1.27 & 0.29 & Rendah \\
Kemurungan & 1.08 & 0.22 & Rendah \\
\hline Keseluruhan (Kesihatan Psikologi) & 1.27 & 0.25 & Rendah \\
\hline
\end{tabular}

(Tahap: Rendah $=1.00-2.33$, Sederhana $=2.34-3.66$, Tinggi $=3.67-5.00)$

\section{Analisis Inferensi}

Ujian korelasi Pearson adalah ujian yang digunakan untuk menjawab persoalan kajian yang ketiga dalam mengenal pasti perkaitan atau perhubungan antara dua atau lebih pemboleh ubah serta penekanan kepada penentuan sejauh mana kaitan antara pemboleh ubah. Jadual 5 menunjukkan hasil dapatan kajian untuk mengenal pasti kepuasan kerja dan kesihatan psikologi dalam kalangan pekerja wanita di KBS. Jadual 5 menunjukkan interpretasi skor pekali korelasi.

Jadual 5: Interpretasi skor pekali korelasi.

\begin{tabular}{cc}
\hline Skor pekali korelasi & Interprestasi skor pekali korelasi \\
\hline $\pm 0.5-1.00$ & Kecil/Lemah \\
$\pm 0.3-0.49$ & Sederhana \\
$\pm 0.1-0.29$ & Teguh/Kukuh \\
\hline
\end{tabular}

Sumber: Cohen (1988) 


\section{Hubungan antara kepuasan kerja dan kesihatan psikologi dalam kalangan pekerja wanita di $\mathrm{KBS}$}

Analisis korelasi Pearson menunjukkan terdapat hubungan negatif yang signifikan antara kepuasan kerja dan kesihatan psikologi dalam kalangan pekerja wanita di KBS, Putrajaya dengan nilai $r=-$ 0.392 dan sig $=0.000$ ( $p>0.05)$. Ini menunjukkan bahawa hipotesis nul (Ho1) ditolak. Hasil analisis menunjukkan kekuatan hubungan antara kepuasan kerja dan kesihatan psikologi dalam kalangan pekerja wanita di KBS, Putrajaya adalah sederhana. Ini menunjukkan hubungan korelasi pearson berada di tahap sederhana secara negatif iaitu apabila kepuasan kerja meningkatkan maka kesihatan psikologi akan menurun. Justeru itu, dapatan ini bermaksud kepuasan kerja mempengaruhi kesihatan psikologi dalam kalangan pekerja wanita di KBS, Putrajaya.

Jadual 6: Pekali korelasi antara kepuasan kerja dan kesihatan psikologi dalam kalangan pekerja wanita di KBS Putrajaya

\begin{tabular}{cccc}
\hline Hubungan & \multicolumn{2}{c}{ Kepuasan Kerja } & Interpretasi \\
\cline { 2 - 3 } & $\mathbf{r}$ & Sig. & \\
\hline Kesihatan Psikologi & -.392 & .000 & Sederhana \\
\hline
\end{tabular}

\section{Perbincangan Kajian}

Dapatan kajian yang diperoleh daripada analisis deskriptif terhadap faktor dalam konstruk kepuasan kerja dan kesihatan psikologi telah dilaporkan dan dibentangkan dalam bab 4. Bagi faktor kepuasan kerja hasil kajian bahawa faktor penyeliaan mempunyai nilai $\min (\min =4.02, \mathrm{SP}=0.58)$ berada pada tahap yang tinggi dan diikuti oleh faktor suasana kerja, kenaikan pangkat, gaji dan rakan sekerja. Secara keseluruhan menunjukkan bahawa skor kepuasan kerja dalam kalangan pekerja wanita di KBS berada pada tahap yang tinggi.

Hasil kajian menunjukkan bahawa faktor utama kepuasan kerja di kalangan wanita pekerja di Kementerian Belia dan Sukan, Putrajaya adalah penyeliaan. Ini kerana, pekerja wanita di KBS Putrajaya menunjukkan bahawa wujudnya perkaitan yang kuat antara penyeliaan dengan tahap kepuasan kerja. Kebanyakan mereka berpuas hati dengan corak penyeliaan yang diamalkan sekarang. Kajian lepas yang dikaji oleh Hanis dan Raudhiah (2018), juga menunjukkan hasil yang hampir sama kerana penyeliaan masih dalam faktor tertinggi dalam mempengaruhi kepuasan kerja yang mana responden menyatakan bahawa mereka akan mematuhi arahan orang yang berjawatan lebih tinggi darinya selagi arahan tersebut dirasakan munasabah untuk dituruti.

Seterusnya, bagi faktor kesihatan psikologi hasil kajian mendapati bahawa faktor kegelisahan dan insomnia mempunyai nilai $\min (\mathrm{min}=1.32, \mathrm{SP}=0.32)$ berada pada tahap yang paling tinggi dan diikuti oleh disfungsi sosial dan kemurungan. Secara keseluruhan menunjukkan bahawa skor kepuasan kerja dalam kalangan pekerja wanita di KBS berada pada tahap rendah. Hasil kajian menunjukkan bahawa faktor utama kesihatan psikologi antara pekerja wanita di Kementerian Belia dan Sukan, Putrajaya adalah kegelisahan dan insomnia. Untuk mengukuhkan lagi dapatan ini, kajian yang dilaksanakan oleh Taylor (2011), juga menunjukkan bahawa gejala kegelisahan dan insomnia mengakibatkan peningkatan kesihatan mental. Secara rasional, tidak ramai yang peduli dengan cara amalan tidur yang tidak teratur sebenarnya boleh mempengaruhi kesihatan psikologi misalnya, jadual kerja yang benar-benar mempengaruhi tabiat tidur atau gangguan emosi yang boleh menyebabkan kegelisahan dan insomnia terutama bagi wanita pekerja.

Dapatan ini disokong oleh kajian Klai dan Bahrin (2020) yang menegaskan bahawa kegelisahan dan insomnia ini merupakan satu keadaan perubatan yang serius sehingga memberi kesan kepada badan, pemikiran, dan tingkah laku individu. Ia memberi kesan kepada cara pemakanan dan tidur individu, cara pemikiran individu terhadap dirinya sendiri, dan juga cara individu memikirkan sesuatu perkara. Perubahan yang kerap dan beban kerja yang banyak ini sedikit sebanyak telah menyebabkan para 
pekerja terkesan untuk menghadapi masalah tekanan yang berkemungkinan besar akan membawa kepada masalah kegelisahan dan insomnia.

Analisis korelasi Pearson menunjukkan terdapat hubungan yang signifikan antara kepuasan kerja dan kesihatan psikologi dalam kalangan pekerja wanita di KBS, Putrajaya dengan nilai $r=-0.392$ dan sig $=$ 0.000 ( $p>0.05$ ) serta mempunyai kekuatan hubungan yang negatif pada tahap sederhana. Menurut hasil kajian daripada statistik dunia menunjukkan bahawa kesihatan psikologi di tempat kerja adalah masalah yang semakin meningkat di kebanyakan organisasi dan mempunyai kesan yang negatif ke atas pekerja. Kesihatan psikologi di tempat kerja merupakan masalah global yang perlu ditangani dengan serius. Miller dan Bornstein (2013), menegaskan bahawa faktor kesihatan psikologi boleh mempengaruhi serta menjejaskan aspek peribadi seseorang seperti menjejaskan hubungan, kepuasan kerja dan kesihatan diri. Kesihatan psikologi turut berkaitan dengan kecederaan seperti gangguan emosi, gangguan tidur, dan gangguan perasaan (Brock \& Buokley, 2012).

Justeru itu, menurut (Lessard \& Baldwin, 1999; Manshor et al., 2003; Rees \& Redfern, 2000; Mohd Makhbul et al., 2020) menyatakan sebenarnya masalah kesihatan psikologi di tempat kerja adalah isu global yang tidak boleh dielakkan kerana ianya satu masalah yang paling minimum dan masalah itu adalah lambang kejayaan organisasi dalam pengurusan dan pembangunan sumber manusia. Tahap kesihatan psikologi yang minimum akan menjadikan seseorang pekerja itu lebih berdaya saing dan produktiviti organisasi terus meningkat. Jika tahap kesihatan psikologi yang berlebihan boleh menjejaskan aspek keselamatan dan kesihatan pekerjaan. Ia berpunca daripada terganggunya psikologi dan fisiologi seseorang individu. Apabila gangguan ini berpanjangan, ia akan menyebabkan kemurungan (Murphy, 1995; Smith, 1994; Mohd Makhbul et al., 2020). Kegelisahan dan insomnia akan menjejaskan tumpuan pekerja terhadap kerja dan boleh menyebabkan peningkatan kadar kemalangan. Jika masalah ini terus mengancam sumber manusia sesebuah organisasi, sudah tentunya kadar kemalangan di tempat kerja akan terus meningkat dan boleh menjejaskan produktiviti sesebuah negara (Rees \& Redfern, 2000).

\section{Kesimpulan}

Secara keseluruhan faktor utama kepuasan kerja dalam kalangan pekerja wanita di Kementerian Belia dan Sukan, Putrajaya adalah penyeliaan kerana mempunyai penyelia yang baik di tempat kerja sangat penting untuk kesihatan mental pekerja. Seterusnya faktor utama kesihatan psikologi di kalangan wanita pekerja di Kementerian Belia dan Sukan, Putrajaya adalah kegelisahan dan insomnia. Ini mungkin terjadi disebabkan oleh tradisi dan budaya masyarakat di Malaysia. Ini kerana, wanita berada di bawah tekanan yang tinggi, dengan penyusunan semula organisasi, kekurangan sokongan dari pengurus dan keseimbangan antara pekerjaan dan kehidupan keluarga, menyebabkan mereka berasa kelesuan.

\section{Rujukan}

Aazami, S., Shamsuddin, K., Akmal, S., \& Azami, G. (2015). The relationship between job satisfaction and psychological/physical health among malaysian working women. Malaysian Journal of Medical Sciences, 22(4), 40-46. https://doi.org/10.1007/s12564-015-9411-8

Alam, S. M. I. (2006). Job Satisfaction of Female Workers in Different Garments Factories in Dhaka City: An Intertemporal Comparison. Daffodil International University Journal of Business and Economics, 1(1), 87-99.

Artz, B. (n.d.). Fringe Benefits and Job Satisfaction By Department of Economics. University of Wisconsin - Whitewater, (Working Paper 08-03).

Baharum, S., Sawai, J. P., \& Rathakrishan, R. B. (1986). Minnesota Satisfaction Questionaire.

Bakan, P. I. (2013). The Relationship between Employees ' Income Level and Employee Job Satisfaction: An Empirical Study. International Journal of Business and Social Science, 4(7), $18-25$. 
Baro, S. Das, \& Mahavidyalaya, B. K. (2014). Abhinav National Monthly Refereed Journal of Research in Commerce \& Management Relationship between Mental Health and Job Satisfaction among Primary School Teachers: A Study With Special Reference To Bongaigaon Abhinav National Monthly Refereed Journal of Research In, 3(8).

Block, J. H., Millán, J. M., Román, C., \& Zhou, H. (2015). Job Satisfaction and Wages of Family Employees. Entrepreneurship: Theory and Practice, 39(2), 183-207. https://doi.org/10.1111/etap.12035

Brock, M. E. \& Buokley, R. B. 2012. The Role of Stress in Workers' Compensation: Past, Present and Future. Public Personnel Management, 41(1), 1-14.

Buljubasic, E. (2008). Relationship with co-workers and job satisfaction, 1-34. Retrieved from http://arno.uvt.nl/show.cgi?fid=81639

Ehsan Malik, M., Qaiser Danish, R., \& Munir, Y. (2012). The Impact of Pay and Promotion on Job Satisfaction: Evidence from Higher Education Institutes of Pakistan. American Journal of Economics, 2(4), 6-9. https://doi.org/10.5923/j.economics.20120001.02

Grapragasem, S., Krishnan, A., \& Mansor, A. N. (2014). Current Trends in Malaysian Higher Education and the Effect on Education Policy and Practice: An Overview. International Journal of Higher Education, 3(1), 85-93. https://doi.org/10.5430/ijhe.v3n1p85

H.a, L., \& Khalid, M. a. (2008). Degrees of discrimination in malaysia. Vasa, 1-38. Retrieved from http://medcontent.metapress.com/index/A65RM03P4874243N.pdf

Habli, N. O. R. A., Ali, Z. M., \& Mustafa, Z. (2017). Kesan Faktor Kepuasan dan Kesetiaan Terhadap, 13(2), 59-68.

Hanis, N. U. R., \& Rosliza, H. (2018). Kepuasan Kerja dalam Kalangan Jururawat di Malaysia, 2018(ICoMM), 246-257.

Jilani, E. M. (2015). Contingent Rewards As a Strategy for Influencing Employee Engagement in Manufacturing Companies: Case Study of Williamson Tea Kenya Limited. International Journal of Business and Commerce, 4(5), 20-59.

Kennedy, K. (2012). 2012 Employee Job Satisfaction and Engagement. Retrieved from http://www.shrm.org/research/surveyfindings/articles/pages/2012employeejobsatisfaction.aspx

Kipps, C. M., Nestor, P. J., Acosta-Cabronero, J., Arnold, R., \& Hodges, J. R. (2009). Understanding social dysfunction in the behavioural variant of frontotemporal dementia: The role of emotion and sarcasm processing. Brain, 132(3), 592-603. https://doi.org/10.1093/brain/awn314

Klai, M. E., \& Bahrin, F. K. (2020). Kesedaran tentang masalah kemurungan dalam kalangan guru, 4(4), 273-284.

Kochhar, K. (2013). Women, Work, and the Economy: Macroeconomic Gains from Gender Equity. IMF Staff Discussion Notes, Number 13/10. Retrieved from http://ideas.repec.org/p/imf/imfsdn/13-10.html

Latif, M. S., Ahmad, M., Muhammad, Q., Ferdoos, A., \& Naeem, H. (2013). Impact of employee' s job satisfaction on organizational performance. European Journal of Business and Management, 5(5), 166-171.

Latiff, A., Marzuki, N., \& Matshah, N. (2014). Work environment problems and psychological health problems and its relationship with job satisfaction. Southeast Asia Psychology...,2,95108.Retrieved from http://www.cseap.edu.my/sapj/index.php/journal/singleJournal/49

Lee, C., Alonso, A., Coombs, J., Mulvey, T., Victor, J., Wessels, K., \& Ng, H. (2016). Employee Job Satisfaction and Engagement: Revitalizing a Changing Workforce, 64. Retrieved from https://www.shrm.org/hr-today/trends-and-forecasting/research-and-surveys/Documents/2016Employee-Job-Satisfaction-and-Engagement-Report.pdf

Lehman, J. (2014). Facets of Job Satisfaction Master of Public Administration.

Martins, N., \& Coetzee, M. (2007). Organisational cullture ,employee satisfaction,perceived leader emtional competency and personality type: An exploratory study in Southern African n enineering company. Journal of Human Resource Management, 5(2), 20-32. https://doi.org/10.4102/sajhrm.v5i2.116

Miller, M. K. \& Bornstein, B. H. 2013. Stress, Trauma, and Wellbeing in the Legal System. New York: Oxford.

Mohd Makhbul, Z., Abdullah, N. L., \& Hashim, N. A. (2020). Kata kunci : Stres, global, kesihatan, persekitaran pekerjaaan, 8(1), 41-59. 
Mumtaz, S., \& Ahmad, Z. (2016). A Gender Based Study on Job Satisfaction among Higher Secondary School Heads in Khyber Pakhtunkhwa , ( Pakistan ), 7(19), 46-62.

Munirah, A. 2018. Wanita lebih mudah alami kemurungan. Kosmo!, 27 Mac 2018.

Murphy, L. R. 1995. Managing Job Stress: An Employee Assistance/Human Resource Management Partnership. Personnel Review, 24(1), 41-50.

Naderi, F. (2013). Studying Relationship Between Nature of Job and Job Satisfaction At Pars Khazar Co of Rasht. Singaporean Journal of Business Economics, and Management Studies, 1(7), 47-50.

Nadinloyi, K. B., Sadeghi, H., \& Hajloo, N. (2013). Relationship Between Job Satisfaction and Employees Mental Health. Procedia - Social and Behavioral Sciences, 84, 293-297. https://doi.org/10.1016/j.sbspro.2013.06.554

Nahar, L., Hossain, A., Rahman, A., \& Bairagi, A. (2013). The Relationship of Job Satisfaction, Job Stress, Mental Health of Government and Non-Government Employees of Bangladesh. Psychology, 04(06), 520-525. https://doi.org/10.4236/psych.2013.46074

National Institute of Mental Health. (2009), 1-8.

Pincus, J.D. (1986). Communication satisfaction, job satisfaction and job performance. Human Communication Research

Proctor, C. (2014). Effective Organizational Communication Affects Employee Attitude, Happiness, and Job Satisfaction. Master of Arts, (May), 1-74.

Raziq, A., \& Maulabakhsh, R. (2015). Impact of Working Environment on Job Satisfaction. Procedia Economics and Finance, 23(October 2014), 717-725. https://doi.org/10.1016/S22125671(15)00524-9

Rees, C. F. \& Redfern, D. (2000). Recognising the Perceived Causes of Stress - A Training and Development Perspective. Industrial and Commercial Training, 32(4), 120-127.

Shagholi, R., Abdolmalki, R., \& Moayedi, A. A. (2011). New approach in Participatory Management, concepts and applications. Procedia - Social and Behavioral Sciences, 15, 251-255. https://doi.org/10.1016/j.sbspro.2011.03.082

Siti Fardaniah abdul aziz. (2018). Bagaimana Organisasi boleh Memotivasikan Pekerja untuk Belajar dalam Latihan : Persepsi Ahli Akademik, 88, 5-20.

Smith, S. L. 1994. Combating Stress. Occupational Hazards, 56(3), 57-59.

Sypniewska, B. A. (2014). Evaluation of factors influencing job satisfaction. Contemporary Economics, 8(1), 57-72. https://doi.org/10.5709/ce.1897-9254.131

Taylor, D. J., Gardner, C. E., Bramoweth, A. D., Williams, J. M., Roane, B. M., Grieser, E. A., \& Tatum, J. I. (2011). Insomnia and mental health in college students. Behavioral Sleep Medicine, 9(2), 107-116. https://doi.org/10.1080/15402002.2011.557992

Trivellas, P., Reklitis, P., \& Platis, C. (2013). The Effect of Job Related Stress on Employees' Satisfaction: A Survey in Health Care. Procedia - Social and Behavioral Sciences, 73, 718-726. https://doi.org/10.1016/j.sbspro.2013.02.110

Yin-Fah, B., \& Paim, L. (2010). The future of the Malaysian older employees: An exploratory study. International Journal of Business and Management, 5(4), 125-132. https://doi.org/10.5539/ijbm.v5n4p124

Zubaidah, L. (2013). Pengaruh Faktor Komunikasi, Kepribadian Ekstraversi, dan Kepribadian Ketelitian Terhadap Prestasi Kerja. Jurnal Ilmu Manajemen (JIM), 1(1). 